\title{
Translocation of non-lytic antimicrobial peptides and bacteria penetrating peptides across the inner membrane of the bacterial envelope
}

\author{
Jakob Frimodt-Møller ${ }^{1} \cdot$ Christopher Campion ${ }^{2} \cdot$ Peter E. Nielsen ${ }^{2} \cdot$ Anders Løbner-Olesen $^{1}$ (C)
}

Received: 13 August 2021 / Revised: 28 September 2021 / Accepted: 6 October 2021 / Published online: 8 November 2021

(c) The Author(s) 2021

\begin{abstract}
The increase in multidrug-resistant pathogenic bacteria has become a problem worldwide. Currently there is a strong focus on the development of novel antimicrobials, including antimicrobial peptides (AMP) and antimicrobial antisense agents. While the majority of AMP have membrane activity and kill bacteria through membrane disruption, non-lytic AMP are non-membrane active, internalize and have intracellular targets. Antimicrobial antisense agents such as peptide nucleic acids (PNA) and phosphorodiamidate morpholino oligomers (PMO), show great promise as novel antibacterial agents, killing bacteria by inhibiting translation of essential target gene transcripts. However, naked PNA and PMO are unable to translocate across the cell envelope of bacteria, to reach their target in the cytosol, and are conjugated to bacteria penetrating peptides (BPP) for cytosolic delivery. Here, we discuss how non-lytic AMP and BPP-PMO/PNA conjugates translocate across the cytoplasmic membrane via receptor-mediated transport, such as the cytoplasmic membrane transporters SbmA, MdtM/YjiL, and/or YgdD, or via a less well described autonomous process.
\end{abstract}

Keywords Non-lytic antimicrobial peptides $\cdot$ Bacteria penetrating peptides $\cdot$ Antimicrobial antisense agents $\cdot$ Bacterial membranes

\section{Introduction}

Antimicrobial resistance is now a global problem, that predominantly is driven by the exaggerated use of antibiotics in human medicine and agriculture (Davies et al. 2013). One solution to ensure a viable option to treat bacterial infection in the future is the discovery and development of novel antibiotics, including antimicrobial peptides (AMP) (Shagaghi

Communicated by Michael Polymenis.

Jakob Frimodt-Møller

jakob.frimodtmoller@bio.ku.dk

$\triangle$ Anders Løbner-Olesen

lobner@bio.ku.dk

1 Department of Biology, Center for Peptide-Based Antibiotics, University of Copenhagen, Copenhagen, Denmark

2 Department of Cellular and Molecular Medicine, Center for Peptide-Based Antibiotics, Faculty of Health and Medical Sciences, The Panum Institute, University of Copenhagen, Copenhagen, Denmark et al. 2018) and antimicrobial antisense agents (Hegarty and Stewart 2018; Pifer and Greenberg 2020). AMPs are structurally diverse and widespread peptides, many of which are present in biological protection systems of a variety of organisms including vertebrates, plants, fungi, and bacteria, e.g. as an integral part of the innate immune system in vertebrates. The majority of AMPs are membrane-active, killing bacteria by membrane disruption, while a few nonlytic AMPs act on intracellular targets. It is well established that non-membrane active AMP translocate across the bacterial cell envelope without causing damage (Boman et al. 1993; Casteels and Tempst 1994; Castle et al. 1999; Knappe et al. 2010; Podda et al. 2006) before binding to intracellular targets.

Antimicrobial antisense agents inhibit gene expression at the translational level via specific binding to sequence complementary mRNA of essential genes or to essential sites of rRNA, leading to growth cessation. Due to their biological stability, neutral charge, high binding affinity and specificity for sequence complementary RNA, synthetic nucleic acid analogs such as peptide nucleic acids (PNA) or phosphorodiamidate morpholino oligomers (PMO) are 
preferred as antimicrobial antisense agents (Summerton and Weller 1997; Good and Nielsen 1998a; Wesolowski et al. 2011). Antimicrobial antisense PNAs and PMOs are usually 10-12 bp long (Dryselius et al. 2003; Deere et al. 2005; Goltermann and Nielsen 2020), i.e., (MW > 3000), larger than traditional small-molecule antibiotics (MW $\leq 1000 \mathrm{Da})$, and if unmodified are unable to pass through the cell envelope (Wittung et al. 1995; Good and Nielsen 1998a, b; Good et al. 2000). To improve cytosolic delivery antimicrobial antisense agents can be covalently attached to bacteria-penetrating peptides (BPP) (Good et al. 2001; Geller et al. 2003). BPP constitute a group of peptides of natural or synthetic origin with bacterial membrane translocation capabilities, usually sharing some common characteristics such as being cationic, but also having a content of hydrophobic amino acids. Indeed, these characteristics are to a large extent shared with AMPs as well as with cell-penetrating peptides [CPP, used for cytoplasmic delivery in eukaryotic cells (Ruseska and Zimmer 2020)], and most likely reflect physical interaction with negatively charged cell membranes as a common feature involved in the mechanism of action. Consequently, a varying extent of functional overlap between AMP, BPP and CPP is often observed, e.g. in the form of cytotoxicity, but the detailed structure activity relationship differences within and between the groups is quite subtle, and far from fully understood.

The outer membrane of Gram-negative bacteria and the cell wall of Gram-positive bacteria present two different obstacles for peptide translocation. In Gram-positive bacteria AMP and BPP most likely diffuse through undefined pores in the peptidoglycan (Malanovic and Lohner 2016), while in Gram-negative bacteria they are believed to have a poorly understood autonomous uptake, likely involving interactions with lipopolysaccharide, possible outer-membrane bound proteins and/or phospholipids (Li et al. 2017). However, for most non-lytic AMP and BPP the rate-limiting step for translocation to the cytosol is the cytoplasmic membrane ( $\mathrm{Li}$ et al. 2017). At the cytoplasmic membrane, the molecules enter either via autonomous membrane translocation and/or via a specific transporter mechanism. Here, we focus on translocation across the cytoplasmic membrane, with a special emphasis on uptake of non-lytic AMP/BPP in the Gram-negative bacterium Escherichia coli.

\section{Receptor-mediated uptake through the cytoplasmic membrane}

The most well-described receptor-mediated uptake mechanism of non-lytic AMPs and BPPs is through the cytoplasmic membrane ABC transporters SbmA and BacA, belonging to the peptide uptake permease family (Saier 2000). These are found in distantly related species. For instance, SbmA is found in Enterobacteriaceae (Corbalan et al. 2013), and BacA in the genus Mycobacterium (incl. M. tuberculosis) (Domenech et al. 2009) and the alphaproteobacteria Brucella abortus and Sinorhizobium meliloti (Glazebrook et al. 1993; LeVier et al. 2000). In E. coli the 406 amino acid SbmA protein consists of eight transmembrane domains and peptide transport is driven by the electrochemical gradient (Runti et al. 2013). BacA shares high sequence similarity to SbmA (Glazebrook et al. 1993; Ichige and Walker 1997) and a sbmA-deficient E. coli mutant can be complemented by the bacA gene from S. meliloti or M. tyberculosis, indicating functional similarity as transporters (Ichige and Walker 1997; Domenech et al. 2009). While SbmA is a non-essential protein in laboratory settings (Pranting et al. 2008), it has been identified as a virulence factor in E. coli (APEC)(Li et al. 2005), and BacA is required for Rhizobium meliloti symbiosis establishment in plants (Glazebrook et al. 1993) and prolonged $B$. abortus and $M$. tuberculosis infections in mice (LeVier et al. 2000; Domenech et al. 2009).

The uptake mechanism for proline-rich AMP has in $E$. coli primarily been ascribed to transport via SbmA. These peptides include arasin (Paulsen et al. 2016), apidaecin (Mattiuzzo et al. 2007; Krizsan et al. 2015), Bac7 (Mattiuzzo et al. 2007; Runti et al. 2013; Guida et al. 2015), drosocin (Krizsan et al. 2015), oncocin (Krizsan et al. 2015), pyrrhocoricin (Narayanan et al. 2014), PR-39 (Mattiuzzo et al. 2007; Pranting et al. 2008) and Tur1A (Mardirossian et al. 2018) (Fig. 1). Analogously, BacA transports prolinerich AMPs across the cytoplasmic membrane at least in $S$. meliloti (Marlow et al. 2009; Wehmeier et al. 2010). In $E$. coli proline-rich AMPs depend on SbmA for full activity. However, additional cytoplasmic membrane transporters such as the drug/H + antiporter MdtM and the cytoplasmic membrane transporter YgdD play an accessory role to SbmA in the uptake of Tur1A/Bac7/oncocin and arasin, respectively (Krizsan et al. 2015; Paulsen et al. 2016). Thus, bacterial species, most commonly Gram-negative bacteria, containing SbmA/BacA are susceptible to proline-rich AMPs (Marlow et al. 2009). Conversely, species deficient of SbmA/ BacA, such as Pseudomonas aeruginosa, are less susceptible to this class of AMPs (Benincasa et al. 2004; Paulsen et al. 2013; Narayanan et al. 2014; Bluhm et al. 2015; Knappe et al. 2016; Runti et al. 2017). This could also explain why Gram-positive bacteria, in general, are resistant to these. In addition, SbmA transports microcins B17 and B25 (Lavina et al. 1986; Salomon and Farias 1995) as well as the glycopeptide bleomycin (Yorgey et al. 1994; Mattiuzzo et al. 2007) in E. coli, while BacA transports microcins B 17 and B25 in S. meliloti (Ichige and Walker 1997) and bleomycin in both S. meliloti (Ichige and Walker 1997) and M. tuberculosis (Domenech et al. 2009). 


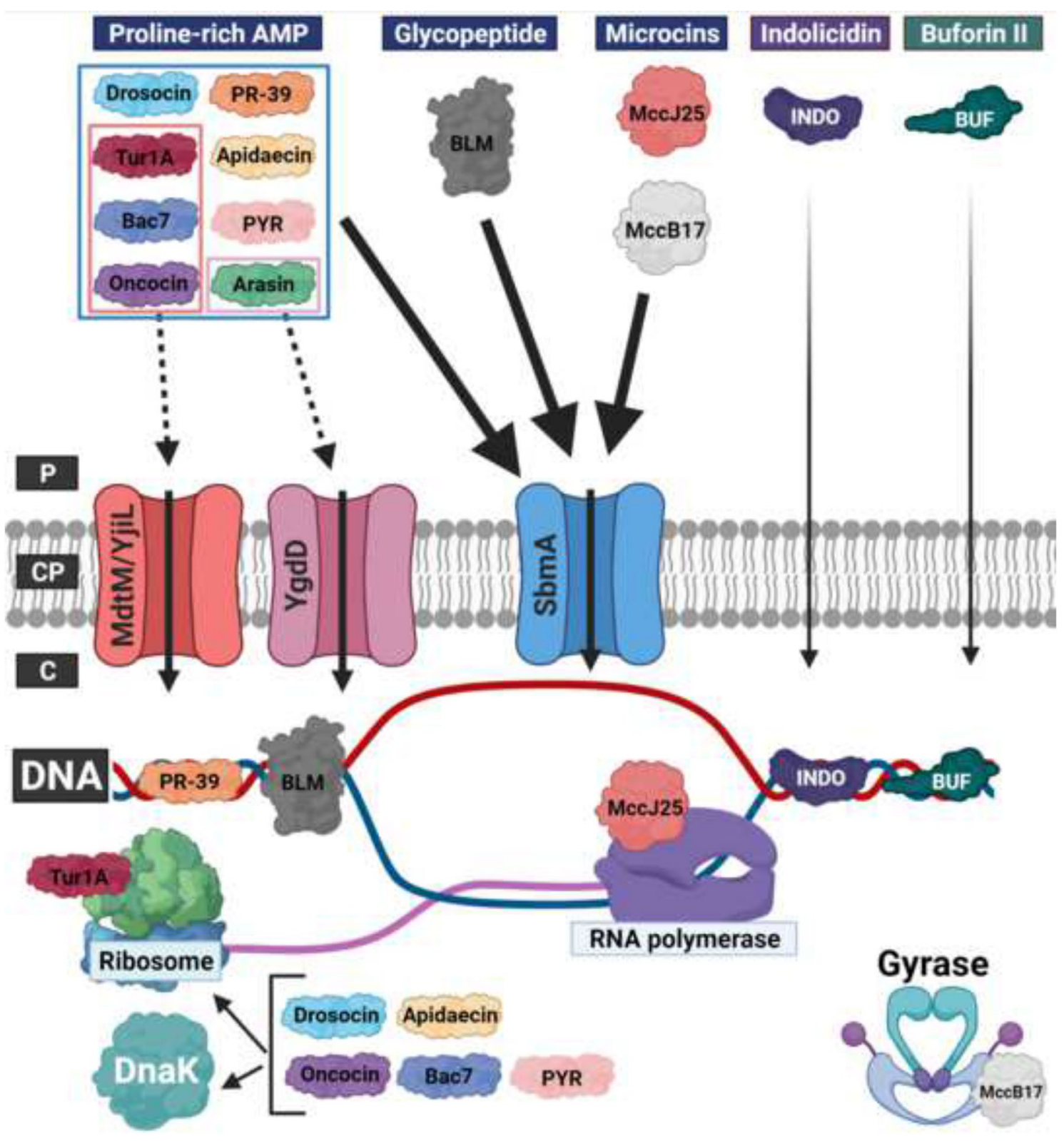

Fig. 1 Uptake of non-lytic AMP across the cytoplasmic membrane. A schematic presentation of the periplasm (P), cytosolic membrane (CP), and cytosol (C) in E. coli. From the periplasm the proline-rich AMP oncocin, Bac7, arasin, apidaecin, PR-39, pyrrhocoricin (PYR), drosocin, and Tur1A translocate across the cytosolic membrane primarily through SbmA (indicated by the full line). MdtM/YjiL plays an accessory role for Tur1A, Bac7, and oncocin, while YgdD plays an accessory role for arasin. Microcins J25 (MccJ25) and B17 (MccB17) and the glycopeptide bleomycin (BLM) are translocated across the cytoplasmic membrane by SbmA. Indolicidin (INDO) and buforin II (BUF) are proposed to translocate across the outer membrane and cytoplasmic membrane by autonomous uptake. In the cyto- sol oncocin, Bac7, apidaecin, PYR, drosocin, and Tur1A binds to the ribosome (Krizsan et al. 2014; Gagnon et al. 2016; Mardirossian et al. 2014, 2018) and with the exception of Tur1A also DnaK [REF (Czihal et al. 2012; Knappe et al. 2011; Kragol et al. 2001; Otvos et al. 2000; Scocchi et al. 2009; Zahn et al. 2014; Zhou Y and W N Chen. 2011)] PR-39, indolicidin, buforin II and BLM to DNA (Yamamoto et al. 1984; Boman et al. 1993; Subbalakshmi and Sitaram 1998; Park et al. 2000; Kosa et al. 2004; Hsu et al. 2005), MccJ25 to the RNA polymerase, and MccB17 to gyrase (Baquero et al. 2019), which in all cases leads to growth arrest. So far, the cytosolic target of arasin has not been elucidated (Paulsen et al. 2013). See text and for details 
PNA conjugated to the lysine/phenylalanine containing BPP (KFF) ${ }_{3} \mathrm{~K}-\mathrm{eg} 1^{1}$ and PMO conjugated to the arginine/ phenylalanine containing BPP $(\mathrm{RFF})_{3} \mathrm{R}-\mathrm{Ahx}-\beta$-alanine ${ }^{2}$ are transported across the cytoplasmic membrane by SbmA in E. coli (Puckett et al. 2012; Ghosal et al. 2013). The $(\mathrm{KFF})_{3} \mathrm{~K}$-eg1 BPP is instrumental for translocation across the outer membrane but has very limited biostability in the periplasm, resulting in peptide-truncation (Yavari et al. 2021). These truncated peptide-PNA conjugates, require SbmA-dependent uptake across the cytoplasmic membrane, while the enzymatically stable D-form of full length $(\mathrm{KFF})_{3} \mathrm{~K}$-eg1-PNA is able to cross in an SbmA-independent manner (visualized in Fig. 2) (Yavari et al. 2021). Arginine containing BPPs usually have an autonomous uptake across the cytoplasmic membrane (see below), suggesting that $(\mathrm{RFF})_{3} \mathrm{R}-\mathrm{Ahx}-\beta$-alanine might face similar biostability issues in the periplasm as $(\mathrm{KFF})_{3} \mathrm{~K}$-eg1. Compared to the straightforward resistance development to (KFF) ${ }_{3} \mathrm{~K}$-eg1PNA, through loss of SbmA (Ghosal et al. 2013), resistance development to peptide-PNA translocating through an autonomous uptake in $E$. coli requires multiple mutations and are difficult to obtain(Frimodt-Møller et al. 2021). Thus, emphasizing the importance of improving carrier stability when optimizing/designing BPPs for delivery of antimicrobial peptides in bacteria.

\section{Autonomous uptake across the cytoplasmic membrane}

Some non-lytic AMPs and BPPs do not internalize through a receptor-mediated uptake. Hypothesis derived from in silico and in vitro studies has been put forward to explain this autonomous translocation (Rothbard et al. 2004; Stanzl et al. 2013; Herce et al. 2014; Li et al. 2017), including the "selfpromoted uptake" model proposed by Hancock and Chappel (Hancock and Chapple 1999). Nonetheless, it remains poorly understood how these molecules reach the cytosol in bacteria. The non-lytic AMPs indolicidin, a tryptophan/prolinerich AMP (Selsted et al. 1992), and buforin II (Park et al. 1996) enters the cytoplasm without disrupting membrane integrity (Fig. 1). Buforin II although non-proline-rich has a proline residue at position 11 (Yi et al. 1996), which plays a key role in effective translocation (Kobayashi et al. 2004).

Uptake mechanisms for arginine-rich peptides differ significantly between mammalian and bacterial cells, as endocytosis (for which no analogue exists in bacteria) is the predominant uptake pathway in mammalian cells (Ruseska and Zimmer 2020). However, very recent results are beginning to shed new light on the SbmA independent, autonomous uptake of at least arginine-rich BPPs and AMPs. Here, an activated Cpx-response was shown to confer resistance to the (R-X-R) $)_{4}$-Ahx- $\beta$-alanine-PNA conjugate in E. coli (Frimodt-Møller et al. 2021). The activated Cpx-response resulted in the downregulation of respiratory genes leading to a decreased cytoplasmic membrane potential. This indicates an indirect autonomous but energy-dependent uptake mechanism, relying on a high membrane potential, for antimicrobials conjugated to such an arginine-rich BPP (Fig. 2) (Frimodt-Møller et al. 2021). In agreement, an activated $\mathrm{Cpx}$-response also conferred a decreased susceptibility to aminoglycosides and another arginine-rich $\mathrm{BPP}\left(\mathrm{R}_{11}\right)$ conjugated to a peptide targeting the DNA sliding clamp (Frimodt-Møller et al. 2021).

These findings are of general interest for several reasons. First of all, they confirm and stress, that also for cationic peptides with autonomous, and thus transporter independent uptake, crossing the inner membrane is the main barrier in (Gram-negative) bacteria. Furthermore, the findings shed important light on the mechanism for crossing the inner membrane, by demonstrating that this requires a significant negative membrane potential to energetically drive the passage. Resistance development towards receptor translocated AMPs and BPPs are in many cases straightforward, ex. by loss of the transporter/receptor (Ghosal et al. 2013). Conversely, resistance development towards non-receptor translocated BPPs (and AMPs) are difficult to obtain and come with a high fitness cost (Frimodt-Moller et al. 2021). Thus, the uptake route is an important parameter to consider when designing/searching for novel non-lytic AMPs or BPPs, preferable pursuing a non-receptor mediated uptake.

\footnotetext{
${ }^{1} \mathrm{~K}$ refers to lysine, $\mathrm{F}$ refers phenylalanine, and eg1 refers to 8-amino-3,6-dioxaoctanoic acid.

${ }^{2} \mathrm{R}$ refers arginine and Ahx refers to 6-aminohexanoic acid.
} 


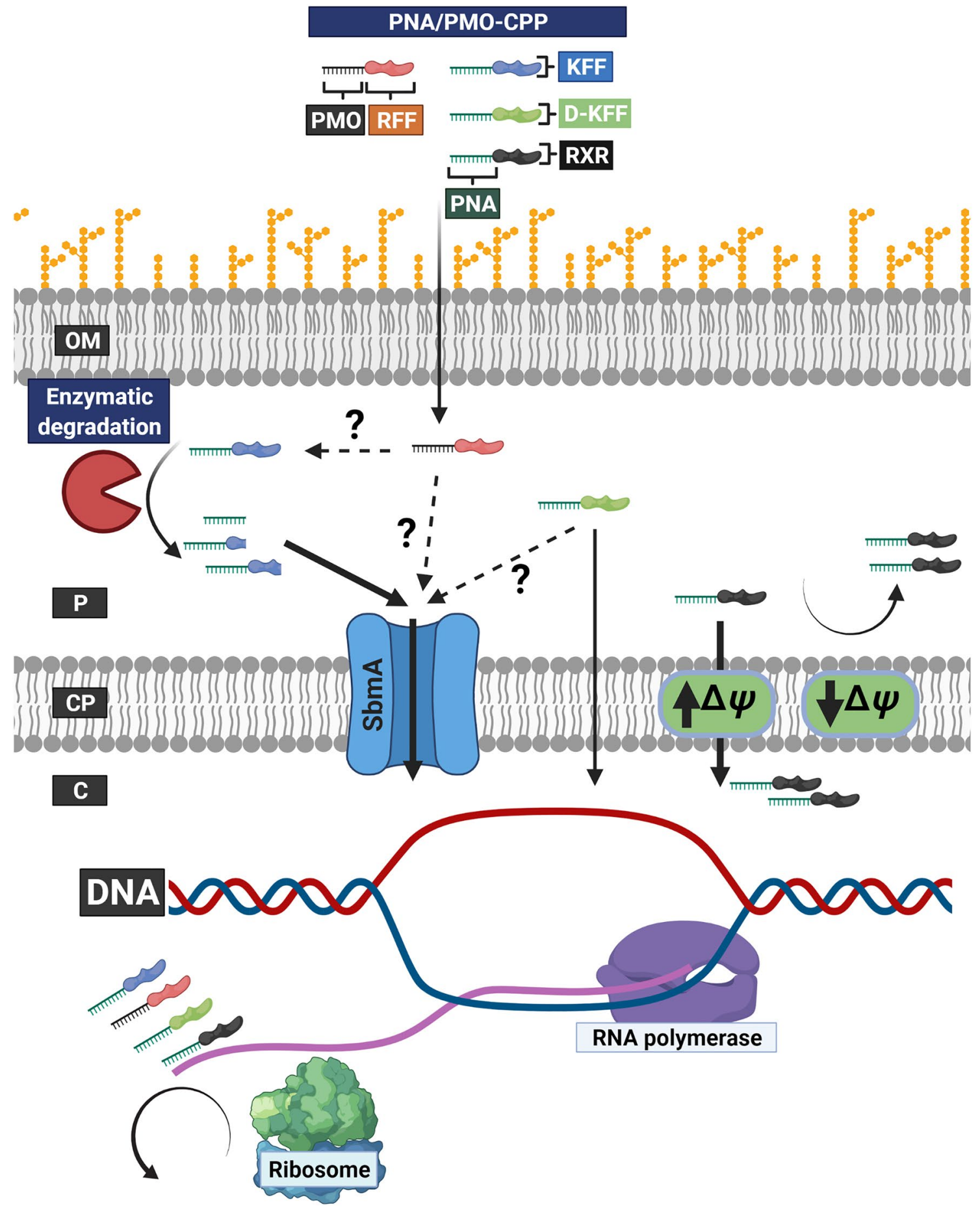

Fig. 2 Uptake of PNA/PMO-BPP across the cell envelope. A schematic presentation of the outer membrane $(\mathrm{OM})$, periplasm $(\mathrm{P})$, cytosolic membrane (CP), and cytosol (C) in E. coli. The biostability of PNA conjugated to $(\mathrm{KFF})_{3} \mathrm{~K}$-eg1 (PNA-KFF), and possible also PMO conjugated to $(\mathrm{RFF})_{3} \mathrm{R}$-Ahx- $\beta$-alanine (indicated by a dashed line), is limited leading to truncated peptide-PNA conjugants in the periplasm. Truncated PNA-KFF conjugates and truncated/full-length PMO conjugated to $(\mathrm{RFF})_{3} \mathrm{R}-\mathrm{Ahx}-\beta$-alanine are translocated across the cytoplasmic membrane by SbmA. The PNA conjugated to the D-form of $(\mathrm{KFF})_{3}$ K-eg1 (PNA-D-KFF) has highly increased bio- stability compared to the L-form, and this peptide-PNA conjugate is believed to translocate across the cytoplasmic membrane by autonomous uptake (indicated by a full line). However, uptake through SbmA cannot be excluded (indicated by a dashed line). PNA conjugated to (R-X-R) $)_{4}$-Ahx- $\beta$-alanine (PNA-RXR) requires a high $\Delta \Psi$ across the cytoplasmic membrane to translocate, while a low $\Delta \Psi$ results in a decreased uptake. In the cytosol PNA/PMO-BPP binds to the mRNA of an essential gene, which leads to growth arrest. See text for details 
Author contributions JFM, CC, PEN, and ALO drafted the manuscript.

Funding This research was funded by the Novo Challenge Center for Peptide-Based Antibiotics grant (NNF16OC0021700), Villum Fonden (grant numbers: 35894, 36297).

\section{Declarations}

Conflict of interest The authors declare that they have no competing interests.

Open Access This article is licensed under a Creative Commons Attribution 4.0 International License, which permits use, sharing, adaptation, distribution and reproduction in any medium or format, as long as you give appropriate credit to the original author(s) and the source, provide a link to the Creative Commons licence, and indicate if changes were made. The images or other third party material in this article are included in the article's Creative Commons licence, unless indicated otherwise in a credit line to the material. If material is not included in the article's Creative Commons licence and your intended use is not permitted by statutory regulation or exceeds the permitted use, you will need to obtain permission directly from the copyright holder. To view a copy of this licence, visit http://creativecommons.org/licenses/by/4.0/.

\section{References}

Baquero F, Lanza VF, Baquero MR, Del Campo R, Bravo-Vazquez DA (2019) Microcins in enterobacteriaceae: peptide antimicrobials in the eco-active intestinal chemosphere. Front Microbiol 10:2261. https://doi.org/10.3389/fmicb.2019.02261

Benincasa M, Scocchi M, Podda E, Skerlavaj B, Dolzani L, Gennaro R (2004) Antimicrobial activity of Bac7 fragments against drugresistant clinical isolates. Peptides 25:2055-2061. https://doi.org/ 10.1016/j.peptides.2004.08.004

Bluhm ME, Knappe D, Hoffmann R (2015) Structure-activity relationship study using peptide arrays to optimize Api137 for an increased antimicrobial activity against $P$ seudomonas aeruginosa. Eur J Med Chem 103:574-582. https://doi.org/10.1016/j.ejmech. 2015.09.022

Boman HG, Agerberth B, Boman A (1993) Mechanisms of action on Escherichia coli of cecropin P1 and PR-39, two antibacterial peptides from pig intestine. Infect Immun 61:2978-2984. https://doi. org/10.1128/IAI.61.7.2978-2984.1993

Casteels P, Tempst P (1994) Apidaecin-type peptide antibiotics function through a non-poreforming mechanism involving stereospecificity. Biochem Biophys Res Commun 199:339-345. https://doi. org/10.1006/bbrc.1994.1234

Castle M, Nazarian A, Yi SS, Tempst P (1999) Lethal effects of apidaecin on Escherichia coli involve sequential molecular interactions with diverse targets. J Biol Chem 274:32555-32564. https://doi. org/10.1074/jbc. 274.46 .32555

Corbalan N, Runti G, Adler C, Covaceuszach S, Ford RC, Lamba D, Beis K, Scocchi M, Vincent PA (2013) Functional and structural study of the dimeric inner membrane protein SbmA. J Bacteriol 195:5352-5361. https://doi.org/10.1128/JB.00824-13

Czihal P et al (2012) Api88 is a novel antibacterial designer peptide to treat systemic infections with multidrug-resistantGram-negative pathogens. ACS Chem Biol 7(7):1281-1291

Davies SC, Fowler T, Watson J, Livermore DM, Walker D (2013) Annual report of the chief medical officer: infection and the rise of antimicrobial resistance. Lancet 381:1606-1609. https://doi. org/10.1016/S0140-6736(13)60604-2

Deere J, Iversen P, Geller BL (2005) Antisense phosphorodiamidate morpholino oligomer length and target position effects on genespecific inhibition in Escherichia coli. Antimicrob Agents Chemother 49:249-255. https://doi.org/10.1128/AAC.49.1.249-255. 2005

Domenech P, Kobayashi H, LeVier K, Walker GC, Barry CE 3rd (2009) BacA, an ABC transporter involved in maintenance of chronic murine infections with Mycobacterium tuberculosis. J Bacteriol 191:477-485. https://doi.org/10.1128/JB.01132-08

Dryselius R, Aswasti SK, Rajarao GK, Nielsen PE, Good L (2003) The translation start codon region is sensitive to antisense PNA inhibition in Escherichia coli. Oligonucleotides 13:427-433. https://doi. org/10.1089/154545703322860753

Frimodt-Moller J, Koulouktsis A, Charbon G, Otterlei M, Nielsen PE, Lobner-Olesen A (2021) Activating the Cpx response induces tolerance to antisense PNA delivered by an arginine-rich peptide in Escherichia coli. Mol Ther Nucleic Acids 25:444-454. https:// doi.org/10.1016/j.omtn.2021.06.009

Frimodt-Møller J, Koulouktsis A, Charbon G, Otterlei M, Nielsen PE, Løbner-Olesen A (2021) Activation of the Cpx-envelope stress response system promotes tolerance to antibacterials delivered by arginine-rich peptides and aminoglycosides in Escherichia coli. Mol Ther. https://doi.org/10.1016/j.omtn.2021.06.009

Gagnon MG, Roy RN, Lomakin IB, Florin T, Mankin AS, Steitz TA (2016) Structures of proline-rich peptides bound to the ribosome reveal a common mechanism of protein synthesis inhibition. Nucleic Acids Res 44:2439-2450. https://doi.org/10.1093/nar/ gkw018

Geller BL, Deere JD, Stein DA, Kroeker AD, Moulton HM, Iversen PL (2003) Inhibition of gene expression in Escherichia coli by antisense phosphorodiamidate morpholino oligomers. Antimicrob Agents Chemother 47:3233-3239. https://doi.org/10.1128/aac.47. 10.3233-3239.2003

Ghosal A, Vitali A, Stach JE, Nielsen PE (2013) Role of SbmA in the uptake of peptide nucleic acid (PNA)-peptide conjugates in $E$. coli. ACS Chem Biol 8:360-367. https://doi.org/10.1021/cb300 $434 \mathrm{e}$

Glazebrook J, Ichige A, Walker GC (1993) A Rhizobium meliloti homolog of the Escherichia coli peptide-antibiotic transport protein SbmA is essential for bacteroid development. Genes Dev 7:1485-1497. https://doi.org/10.1101/gad.7.8.1485

Goltermann L, Nielsen PE (2020) PNA antisense targeting in bacteria: determination of antibacterial activity (MIC) of PNA-peptide conjugates. Methods Mol Biol 2105:231-239. https://doi.org/10. 1007/978-1-0716-0243-0_14

Good L, Nielsen PE (1998a) Antisense inhibition of gene expression in bacteria by PNA targeted to mRNA. Nat Biotechnol 16:355-358. https://doi.org/10.1038/nbt0498-355

Good L, Nielsen PE (1998b) Inhibition of translation and bacterial growth by peptide nucleic acid targeted to ribosomal RNA. Proceed Natl Acad Sci USA 95:2073-2076

Good L, Sandberg R, Larsson O, Nielsen PE, Wahlestedt C (2000) Antisense PNA effects in Escherichia coli are limited by the outermembrane LPS layer. Microbiology 146:2665-2670. https://doi. org/10.1099/00221287-146-10-2665 (Pt 10)

Good L, Awasthi SK, Dryselius R, Larsson O, Nielsen PE (2001) Bactericidal antisense effects of peptide-PNA conjugates. Nat Biotechnol 19:360-364. https://doi.org/10.1038/86753

Guida F, Benincasa M, Zahariev S, Scocchi M, Berti F, Gennaro R, Tossi A (2015) Effect of size and N-terminal residue characteristics on bacterial cell penetration and antibacterial activity of the proline-rich peptide Bac7. J Med Chem 58:1195-1204. https:// doi.org/10.1021/jm501367p 
Hancock RE, Chapple DS (1999) Peptide antibiotics. Antimicrob Agents Chemother 43:1317-1323. https://doi.org/10.1128/AAC. 43.6.1317

Hegarty JP, Stewart DB Sr (2018) Advances in therapeutic bacterial antisense biotechnology. Appl Microbiol Biotechnol 102:10551065. https://doi.org/10.1007/s00253-017-8671-0

Herce HD, Garcia AE, Cardoso MC (2014) Fundamental molecular mechanism for the cellular uptake of guanidinium-rich molecules. J Am Chem Soc 136:17459-17467. https://doi.org/10.1021/ja507 $790 \mathrm{z}$

Hsu CH, Chen C, Jou ML, Lee AY, Lin YC, Yu YP, Huang WT, Wu SH (2005) Structural and DNA-binding studies on the bovine antimicrobial peptide, indolicidin: evidence for multiple conformations involved in binding to membranes and DNA. Nucleic Acids Res 33:4053-4064. https://doi.org/10.1093/nar/gki725

Ichige A, Walker GC (1997) Genetic analysis of the Rhizobium meliloti bacA gene: functional interchangeability with the Escherichia coli sbmA gene and phenotypes of mutants. J Bacteriol 179:209-216. https://doi.org/10.1128/jb.179.1.209-216.1997

Knappe D, Piantavigna S, Hansen A, Mechler A, Binas A, Nolte O, Martin LL, Hoffmann R (2010) Oncocin (VDKPPYLPRPRPPRRIYNR-NH2): a novel antibacterial peptide optimized against gram-negative human pathogens. J Med Chem 53:5240-5247. https://doi.org/10.1021/jm100378b

Knappe D et al (2011) Rational design of oncocin derivatives with superior protease stabilities and antibacterial activities based on the high-resolution structure of the oncocin-DnaK complex. Chembiochem 12(6):874-876

Knappe D, Ruden S, Langanke S, Tikkoo T, Ritzer J, Mikut R, Martin LL, Hoffmann R, Hilpert K (2016) Optimization of oncocin for antibacterial activity using a SPOT synthesis approach: extending the pathogen spectrum to Staphylococcus aureus. Amino Acids 48:269-280. https://doi.org/10.1007/s00726-015-2082-2

Kobayashi S, Chikushi A, Tougu S, Imura Y, Nishida M, Yano Y, Matsuzaki K (2004) Membrane translocation mechanism of the antimicrobial peptide buforin 2. Biochemistry 43:15610-15616. https://doi.org/10.1021/bi048206q

Kosa JL, Zdraveski ZZ, Currier S, Marinus MG, Essigmann JM (2004) RecN and RecG are required for Escherichia coli survival of bleomycin-induced damage. Mutat Res 554:149-157. https://doi.org/ 10.1016/j.mrfmmm.2004.04.011

Kragol G et al (2001) The antibacterial peptide pyrrhocoricin inhibits the ATPase actions of DnaK and prevents chaperoneassisted protein folding. Biochemistry 40(10):3016-3026

Krizsan A, Volke D, Weinert S, Strater N, Knappe D, Hoffmann R (2014) Insect-derived proline-rich antimicrobial peptides kill bacteria by inhibiting bacterial protein translation at the $70 \mathrm{~S}$ ribosome. Angew Chem Int Ed Engl 53:12236-12239. https://doi.org/ 10.1002/anie.201407145

Krizsan A, Knappe D, Hoffmann R (2015) Influence of the yjiL-mdtM gene cluster on the antibacterial activity of proline-rich antimicrobial peptides overcoming Escherichia coli resistance induced by the missing $S b m A$ transporter system. Antimicrob Agents Chemother 59:5992-5998. https://doi.org/10.1128/AAC.01307-15

Lavina M, Pugsley AP, Moreno F (1986) Identification, mapping, cloning and characterization of a gene $(\operatorname{sbm} A)$ required for microcin B17 action on Escherichia coli K12. J Gen Microbiol 132:1685-1693. https://doi.org/10.1099/00221287-132-6-1685

LeVier K, Phillips RW, Grippe VK, Roop RM 2nd, Walker GC (2000) Similar requirements of a plant symbiont and a mammalian pathogen for prolonged intracellular survival. Science 287:2492-2493. https://doi.org/10.1126/science.287.5462.2492

Li G, Laturnus C, Ewers C, Wieler LH (2005) Identification of genes required for avian Escherichia coli septicemia by signaturetagged mutagenesis. Infect Immun 73:2818-2827. https://doi. org/10.1128/IAI.73.5.2818-2827.2005
Li J, Koh JJ, Liu S, Lakshminarayanan R, Verma CS, Beuerman RW (2017) Membrane active antimicrobial peptides: translating mechanistic insights to design. Front Neurosci 11:73. https:// doi.org/10.3389/fnins.2017.00073

Malanovic N, Lohner K (2016) Gram-positive bacterial cell envelopes: the impact on the activity of antimicrobial peptides. Biochem Biophys Acta 1858:936-946. https://doi.org/10.1016/j. bbamem.2015.11.004

Mardirossian M, Grzela R, Giglione C, Meinnel T, Gennaro R, Mergaert P, Scocchi M (2014) The host antimicrobial peptide Bac71-35 binds to bacterial ribosomal proteins and inhibits protein synthesis. Chem Biol 21:1639-1647. https://doi.org/ 10.1016/j.chembiol.2014.10.009

Mardirossian M, Perebaskine N, Benincasa M, Gambato S, Hofmann S, Huter P, Muller C, Hilpert K, Innis CA, Tossi A, Wilson DN (2018) The dolphin proline-rich antimicrobial peptide Tur1A inhibits protein synthesis by targeting the bacterial ribosome. Cell Chem Biol 25(530-539):e537. https://doi.org/10.1016/j. chembiol.2018.02.004

Marlow VL, Haag AF, Kobayashi H, Fletcher V, Scocchi M, Walker GC, Ferguson GP (2009) Essential role for the BacA protein in the uptake of a truncated eukaryotic peptide in Sinorhizobium meliloti. J Bacteriol 191:1519-1527. https://doi.org/10.1128/ JB.01661-08

Mattiuzzo M, Bandiera A, Gennaro R, Benincasa M, Pacor S, Antcheva N, Scocchi M (2007) Role of the Escherichia coli SbmA in the antimicrobial activity of proline-rich peptides. Mol Microbiol 66:151-163. https://doi.org/10.1111/j.1365-2958.2007. 05903.x

Narayanan S, Modak JK, Ryan CS, Garcia-Bustos J, Davies JK, Roujeinikova A (2014) Mechanism of Escherichia coli resistance to Pyrrhocoricin. Antimicrob Agents Chemother 58:2754-2762. https://doi.org/10.1128/AAC.02565-13

Otvos L Jr et al (2000) Interaction between heat shock proteins and antimicrobial peptides. Biochemistry 39(46):14150-14159

Park CB, Kim MS, Kim SC (1996) A novel antimicrobial peptide from Bufo bufo gargarizans. Biochem Biophys Res Commun 218:408413. https://doi.org/10.1006/bbrc.1996.0071

Park CB, Yi KS, Matsuzaki K, Kim MS, Kim SC (2000) Structureactivity analysis of buforin II, a histone H2A-derived antimicrobial peptide: the proline hinge is responsible for the cell-penetrating ability of buforin II. Proc Natl Acad Sci USA 97:8245-8250. https://doi.org/10.1073/pnas.150518097

Paulsen VS, Blencke HM, Benincasa M, Haug T, Eksteen JJ, Styrvold OB, Scocchi M, Stensvag K (2013) Structure-activity relationships of the antimicrobial peptide arasin 1-and mode of action studies of the $\mathrm{N}$-terminal, proline-rich region. PLoS One 8:e53326. https://doi.org/10.1371/journal.pone.0053326

Paulsen VS, Mardirossian M, Blencke HM, Benincasa M, Runti G, Nepa M, Haug T, Stensvag K, Scocchi M (2016) Inner membrane proteins $Y g d D$ and $S b m A$ are required for the complete susceptibility of Escherichia coli to the proline-rich antimicrobial peptide arasin 1(1-25). Microbiology (Reading) 162:601-609. https://doi. org/10.1099/mic.0.000249

Pifer R, Greenberg DE (2020) Antisense antibacterial compounds. Transl Res 223:89-106. https://doi.org/10.1016/j.trsl.2020.06.001

Podda E, Benincasa M, Pacor S, Micali F, Mattiuzzo M, Gennaro R, Scocchi M (2006) Dual mode of action of Bac7, a proline-rich antibacterial peptide. Biochem Biophys Acta 1760:1732-1740. https://doi.org/10.1016/j.bbagen.2006.09.006

Pranting M, Negrea A, Rhen M, Andersson DI (2008) Mechanism and fitness costs of PR-39 resistance in Salmonella enterica serovar Typhimurium LT2. Antimicrob Agents Chemother 52:2734-2741. https://doi.org/10.1128/AAC.00205-08

Puckett SE, Reese KA, Mitev GM, Mullen V, Johnson RC, Pomraning KR, Mellbye BL, Tilley LD, Iversen PL, Freitag M, Geller 
BL (2012) Bacterial resistance to antisense peptide phosphorodiamidate morpholino oligomers. Antimicrob Agents Chemother 56:6147-6153. https://doi.org/10.1128/AAC.00850-12

Rothbard JB, Jessop TC, Lewis RS, Murray BA, Wender PA (2004) Role of membrane potential and hydrogen bonding in the mechanism of translocation of guanidinium-rich peptides into cells. J Am Chem Soc 126:9506-9507. https://doi.org/10.1021/ja0482536

Runti G, Lopez Ruiz Mdel C, Stoilova T, Hussain R, Jennions M, Choudhury HG, Benincasa M, Gennaro R, Beis K, Scocchi M (2013) Functional characterization of $\operatorname{SbmA}$, a bacterial inner membrane transporter required for importing the antimicrobial peptide Bac7(1-35). J Bacteriol 195:5343-5351. https://doi.org/ $10.1128 / \mathrm{JB} .00818-13$

Runti G, Benincasa M, Giuffrida G, Devescovi G, Venturi V, Gennaro R, Scocchi M (2017) The mechanism of killing by the prolinerich peptide Bac 7(1-35) against clinical strains of Pseudomonas aeruginosa differs from that against other gram-negative bacteria. Antimicrob Agents Chemother. https://doi.org/10.1128/AAC. 01660-16

Ruseska I, Zimmer A (2020) Internalization mechanisms of cell-penetrating peptides. Beilstein J Nanotechnol 11:101-123. https://doi. org/10.3762/bjnano.11.10

Saier MH Jr (2000) Families of transmembrane transporters selective for amino acids and their derivatives. Microbiology (Reading) 146(Pt 8):1775-1795. https://doi.org/10.1099/00221 287-146-8-1775

Salomon RA, Farias RN (1995) The peptide antibiotic microcin 25 is imported through the TonB pathway and the SbmA protein. J Bacteriol 177:3323-3325. https://doi.org/10.1128/jb.177.11. 3323-3325.1995

Scocchi M et al (2009) The proline-rich antibacterial peptide Bac7 binds to and inhibits in vitro themolecular chaperone DnaK. Int J Pept Res Ther 15:147-155

Selsted ME, Novotny MJ, Morris WL, Tang YQ, Smith W, Cullor JS (1992) Indolicidin, a novel bactericidal tridecapeptide amide from neutrophils. J Biol Chem 267:4292-4295

Shagaghi N, Palombo EA, Clayton AHA, Bhave M (2018) Antimicrobial peptides: biochemical determinants of activity and biophysical techniques of elucidating their functionality. World J Microbiol Biotechnol 34:62. https://doi.org/10.1007/s11274-018-2444-5

Stanzl EG, Trantow BM, Vargas JR, Wender PA (2013) Fifteen years of cell-penetrating, guanidinium-rich molecular transporters: basic science, research tools, and clinical applications. Acc Chem Res 46:2944-2954. https://doi.org/10.1021/ar4000554
Subbalakshmi C, Sitaram N (1998) Mechanism of antimicrobial action of indolicidin. FEMS Microbiol Lett 160:91-96. https://doi.org/ 10.1111/j.1574-6968.1998.tb12896.x

Summerton J, Weller D (1997) Morpholino antisense oligomers: design, preparation, and properties. Antisense Nucleic Acid Drug Dev 7:187-195. https://doi.org/10.1089/oli.1.1997.7.187

Wehmeier S, Arnold MFF, Marlow VL, Aouida M, Myka KK, Fletcher V, Benincasa M, Scocchi M, Ramotar D, Ferguson GP (2010) Internalization of a thiazole-modified peptide in Sinorhizobium meliloti occurs by BacA-dependent and -independent mechanisms. Microbiology (Reading) 156:2702-2713. https://doi.org/ 10.1099/mic.0.039909-0

Wesolowski D, Tae HS, Gandotra N, Llopis P, Shen N, Altman S (2011) Basic peptide-morpholino oligomer conjugate that is very effective in killing bacteria by gene-specific and nonspecific modes. Proc Natl Acad Sci USA 108:16582-16587. https://doi. org/10.1073/pnas.1112561108

Wittung P, Kajanus J, Edwards K, Haaima G, Nielsen PE, Norden B, Malmstrom BG (1995) Phospholipid membrane permeability of peptide nucleic acid. FEBS Lett 375:27-29

Yamamoto K, Hiramoto T, Shinagawa H, Fujiwara Y (1984) Genetic activity of bleomycin in Escherichia coli. Chem Biol Interact 48:145-152. https://doi.org/10.1016/0009-2797(84)90116-9

Yavari N, Goltermann L, Nielsen PE (2021) Uptake, stability, and activity of antisense anti-acpP PNA-peptide conjugates in Escherichia coli and the role of SbmA. ACS Chem Biol. https://doi.org/ 10.1021/acschembio.0c00822

Yi GS, Park CB, Kim SC, Cheong C (1996) Solution structure of an antimicrobial peptide buforin II. FEBS Lett 398:87-90. https:// doi.org/10.1016/s0014-5793(96)01193-3

Yorgey P, Lee J, Kordel J, Vivas E, Warner P, Jebaratnam D, Kolter R (1994) Posttranslational modifications in microcin B17 define an additional class of DNA gyrase inhibitor. Proc Natl Acad Sci USA 91:4519-4523. https://doi.org/10.1073/pnas.91.10.4519

Zahn M et al (2014) Structural identification of DnaK binding sites within bovine and sheep bactenecin Bac7. Protein PeptLett 21(4):407-412

Zhou Y, Chen WN (2011) iTRAQ-coupled 2-D LC-MS/MS analysis of cytoplasmic protein profile in Escherichia coli incubated with apidaecin IB. J Proteomics 75(2):511-516

Publisher's Note Springer Nature remains neutral with regard to jurisdictional claims in published maps and institutional affiliations. 